\title{
Flagellate dermatitis caused by shiitake mushrooms *
}

\author{
Dermatite flagelada após a ingestão de fungos shiitake
}

\author{
Lidia Marilia Poppe \\ Hermann Kneitz ${ }^{2}$ \\ Sandrine Benoit ${ }^{1}$
}

\author{
Diana Anders ${ }^{1}$ \\ Eva-Bettina Bröcker ${ }^{3}$
}

\begin{abstract}
Shiitake (Lentinus edodes) is the second most consumed mushroom in the world. It has long been known in Asian medicine for its anticarcinogenic, antihypertensive and serum cholesterol level reduction properties. Nevertheless, the consumption of raw or not well-cooked mushrooms may cause skin eruptions which usually occur 24 to 48 hours after ingestion and are characterized by linearly arranged pruritic erythematous papules and plaques. We present a 36-year-old patient that developed typical symptoms 24 hours after consumption of shiitake mushrooms and summarize therapeutic options and particularities of this disease.

Keywords: Bleomycin; Flagellate dermatitis, Shiitake dermatitis; Shiitake mushrooms

Resumo: Shiitake (Lentinus edodes) é o segundo tipo de cogumelo mais consumido no mundo. Suas propriedades terapêuticas antitumorais, anti-hipertensivas e redutoras dos níveis elevados de colesterol são há muito conhecidas pela população asiática. Após ingestão desse cogumelo, cru ou malcozido, podem desenvolver-se lesões eritematosas lineares, pruriginosas, que surgem após 24 ou 48 horas em todo o corpo. Apresentamos um paciente de 36 anos com anamnese e clínica típicos, e comentamos as alternativas terapêuticas e nuances dessa dermatose.

Palavras-chave: Bleomicina; Dermatite flagelada; Fungos shiitake; Shiitake-dermatite
\end{abstract}

\section{INTRODUCTION}

Shiitake mushroom (Lentinus edodes) is especially used in Asian cuisine and is one of the most consumed mushrooms in the world (Figure 1). In addition, due to its favourable effects such as blood pressure and serum cholesterol level reduction, as well as anticarcinogenic properties in gastric and intestinal adenocarcinomas, it plays an important role in Asian medicine. ${ }^{1}$

In 1977 Nakamura described for the first time a dermatitis or toxicoderma after ingestion of raw or not well-cooked shiitake mushrooms. It usually occurs 24 to 48 hours after ingestion and is characte- rized by pruritic erythematous papules and plaques that are linearly arranged on the trunk and limbs. The eruptions resemble lesions caused by a lash - a "flagellate-like" pattern. ${ }^{1}$

\section{CASE REPORT}

A 36-year-old Caucasian man was admitted to our clinic with pruritic skin eruptions on the trunk and limbs. He reported sudden onset one week before. For about two days he had had fever up to $39^{\circ} \mathrm{C}$ and arthralgy. Treatment with $40 \mathrm{mg}$ methylprednisolone for three days did not relieve symptoms. Because

\footnotetext{
Received on 07.07.2011.

Approved by the Advisory Board and accepted for publication on 25.07.2011.

* Study carried out at the Department of Dermatology,Allergology and Venereology of the University of Würzburg (Universitäetsklinikum Würzburg), Germany. Conflict of interest: None

Financial funding: None

Medical Doctor in Dermatology, Universitäetsklinikum Wuerzburg - Würzburg, Germany.

$\mathrm{PhD}$ in Dermatology and Pathology, Teaching Hospital of the University of Würzburg (Universitäetsklinikum Würzburg), Germany.

Professor of Dermatology and former Head of the Department of Dermatology, Venereology and Allergology, Teaching Hospital of the University of Würzburg (Universitäetsklinikum Würzburg), Germany. 


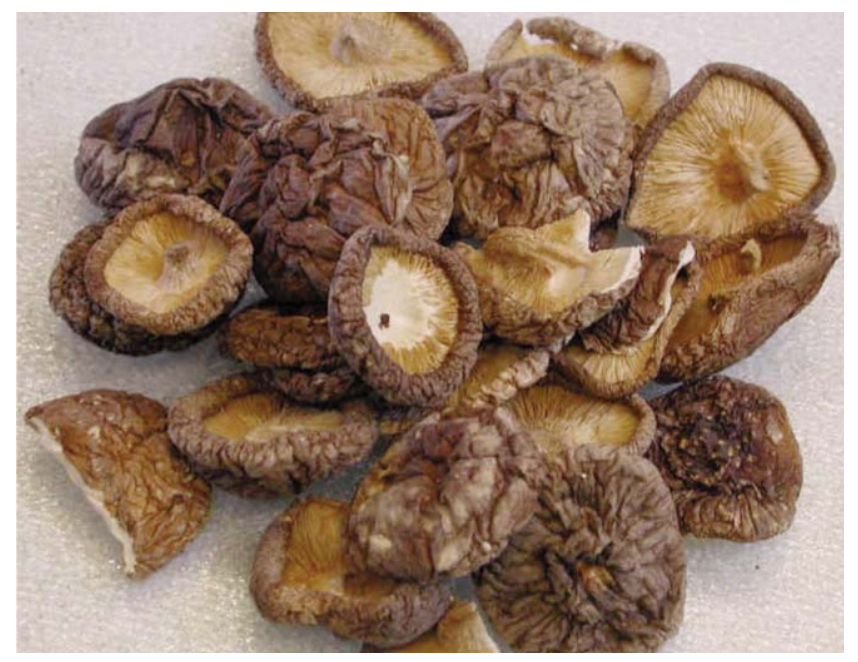

FIGURE 1: Shiitake mushrooms

of the typical clinical picture, dermatitis caused by shiitake mushrooms was suspected. The patient mentioned consumption of rehydrated but uncooked shiitake mushrooms one day before developing skin lesions. He had no respiratory problems, infections or facial oedema. He had taken no new medications or used new topical ointments or hygienic products during that period.

General medical history was remarkable for asthma, arterial hypertension, sleep apnea and hyperthyreosis, but no new treatment was started in relation to the onset of the skin lesions.

Physical examination revealed generalized linear groups of erythematous papules and plaques, predominantly on the trunk, in a flagellate-like pattern (Figure 2). There was no involvement of the face, scalp, or the mucous membranes. Dermographism was urticarial.
Blood tests revealed mild leucocytosis, increased C-reactive protein $(1.58 \mathrm{mg} / \mathrm{dl}$, normal < 0.5$)$ and increased total serum IgE $(264 \mathrm{kU} / 1$, normal $<100)$. Serum lipids, liver and kidneys tests were within the normal range.

Histopathological examination of a skin biopsy showed focal hyperkeratosis, spongiosis, mild dermal oedema and perivascular lymphocytic infiltration with eosinophils (Figure 3).

Due to the typical history and clinical features, we diagnosed flagellate dermatitis caused by shiitake mushrooms, also known as shiitake-dermatitis or toxicoderma. Topical steroids (clobetasol propionate $0.05 \%$ followed by $0.1 \%$ betamethasone valerate cream) were applied. In addition, 5\% polidocanol cream and desloratadine were administered to relieve pruritus. Complete remission was achieved within 10 days.

\section{DISCUSSION}

Lentinan, that is suspected to cause shiitake dermatitis, is a thermolabile polysaccharide extracted from the shiitake mycelia. The pathogenesis of the resulting dermatitis is still unclear, but it has been postulated that lentinan increases the secretion of interleukin-1 and causes vasodilatation. ${ }^{2,3}$ Some patients who were being treated with extract of shiitake mushrooms for gastric and intestinal adenocarcinoma developed a similar skin reaction. ${ }^{3}$

Lentinan is a temperature and light sensitive substance; therefore it has been discussed whether shiitake dermatitis occurs only after ultraviolet exposure. A retrospective study in Japan showed that in $\mathbf{4 4}$ of 94 patients (47\%) the typical erythematous skin lesions developed first on the sun exposed areas. ${ }^{4}$

It has also been discussed if some medications, such as ACE inhibitors or diuretics could either induce or accelerate the development of flagellate derma-

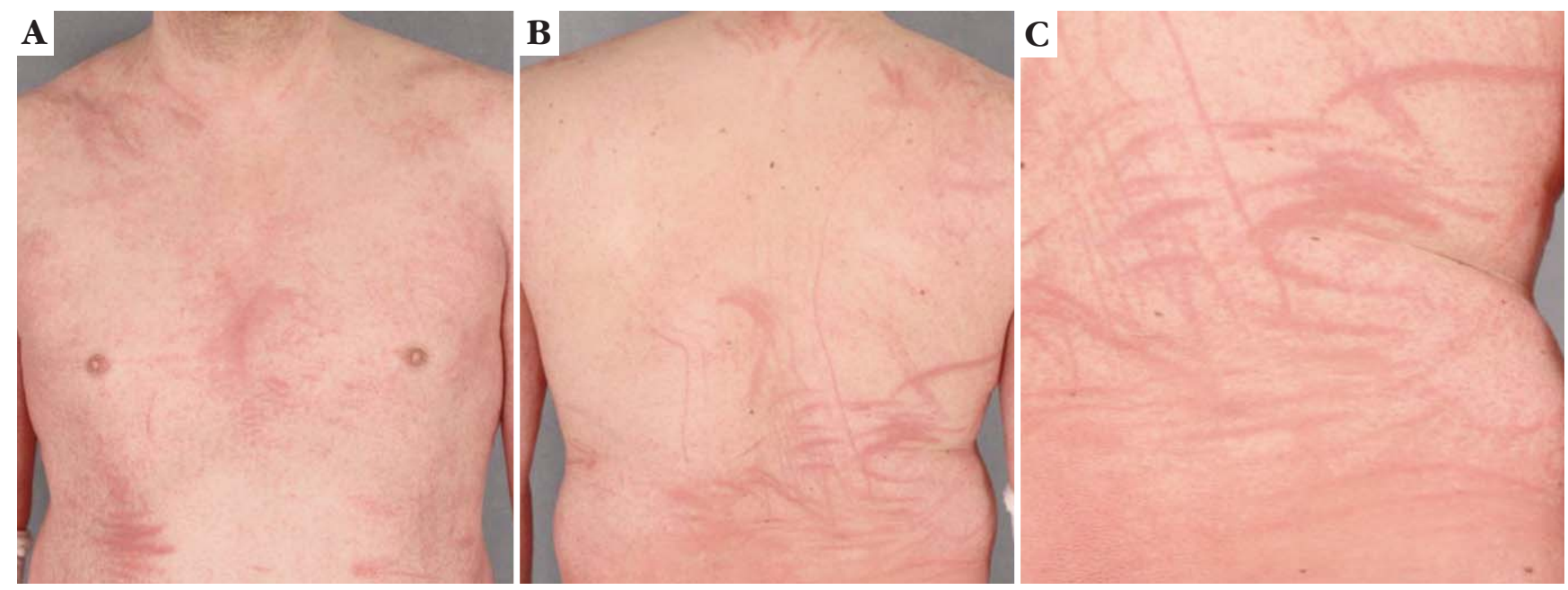

Figure 2: A. and B. Linear groups of erythematous papules and plaques with accentuation on the trunk in a flagellate-like pattern; C. Detail 


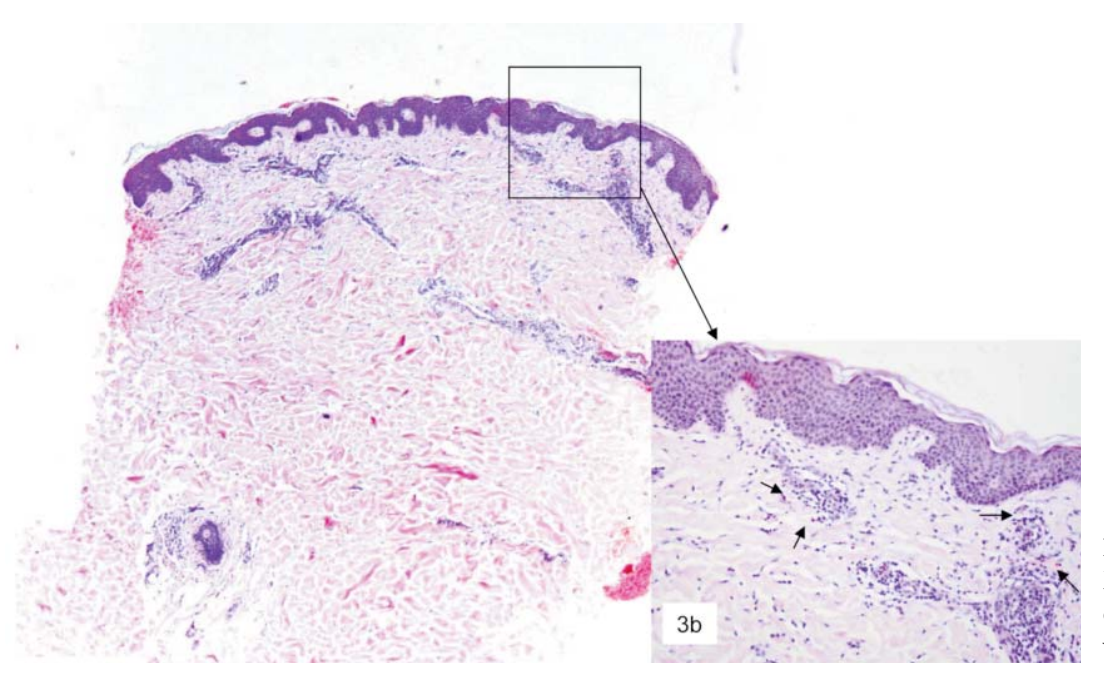

Figure 3: (40x) Histological features showed focal hyperkeratosis, B. (200x) spongiosis, mild dermal oedema and perivascular lymphocytic infiltration with eosinophils

titis after shiitake ingestion. ${ }^{5}$

Differential diagnosis include bleomycin-induced flagellate dermatitis. Bleomycin is a cytostatic drug extrated from Streptomyces verticillus. However, there are some differences in the clinical picture. Mucous membranes are also involved and usually lesions heal with hyperpigmentation. ${ }^{6}$

It takes about two weeks for complete remission of shiitake dermatitis. The symptoms could be treated with antihistaminic drugs, topical corticosteroids and, in severe cases, oral corticosteroids for a short time. ${ }^{7.8}$ As re-exposure could cause another onset of dermatitis, eating shiitake mushrooms, especially raw or not well-cooked should be avoided. ${ }^{9}$

With globalization and popularity of Asian cuisine, cases of flagellate dermatitis after ingestion of shiitake mushrooms may increase, therefore dermatologists should be aware of this disease.

\section{AKNOWLEGDMENTS}

We would like to thank Prof. Dr. Elemir Macedo de Souza for critically reading the manuscript.

\section{REFERENCES}

1. Nakamura T. Shiitake (Lentinus edodes) dermatitis. Contact Dermatitis. 1992;27:65-70

2. Maier T, Herzinger T. Linear dermatitis due to shiitake mushrooms. Hautarzt. 2007;58:1021-2.

3. Curnow P, Tam M. Contact Dermatitis to Shiitake mushroom. Austral J Dermatol. 2003;44:155-7.

4. Hanada K, Hashimoto I. Flagellate mushroom (shiitake) dermatitis and photosensitivity. Dermatology. 1998;197:255-7.

5. Haas N, Vogt R, Sterry W. Shiitake-Dermatitis: flagellate dermatitis after eating mushrooms. Hautarzt. 2001;52:132-5.

6. Dubra P, Ilchyshyn A, Das RN. Bleomycin-induced flagellate erythema. Clin Exp Dermatol. 1991;16:216-7.

7. Mak RKH, Wakelin SH. Shiitake-Dermatitis: the first case reported from a European country. Brit J Dermatol. 2006;154:800-1.

8. Auth M, Weinrich BG, Bauer B, Seitz CS, Bröcker EB, Schön MP. Striate urticarial erythemas on trunk and extremities. J Deutsche Dermatol Gesel. 2005;3:812-4.

9. Garg S, Cockayne SE. Shiitake Dermatitis diagnosed after 16 years! Arch Dermatol. 2008;144:1241-2.

\author{
MAILING ADDRESS: \\ Lidia Marilia Poppe \\ Josef-Schneider-Strasse 2 Haus D8 \\ 97080 Würzburg \\ Deutschland \\ E-mail: lidia.derma@googlemail.com
}

How to cite this article: Poppe LM, Anders D, Kneitz H, Bröcker EB, Benoit S. Flagellate dermatitis caused by shiitake mushrooms. An Bras Dermatol. 2012;87(3):463-5. 